\title{
Implementing circular economy concept by converting cassava pulp and wastewater to biogas for sustainable production in starch industry
}

\section{Ruenrom Lerdlattaporn}

The Joint Graduate School of Energy and Enviroment, King Mongkut's University of Technology Thonburi

\section{Chantaraporn Phalakornkule}

King Mongkut's University of Technology North Bangkok Faculty of Chemical ering

\section{Sivalee Trakulvichean}

Pilot Plant Development and Training Institue, King Mongkut's University of Technology Thonburi

Warinthorn Songkasiri ( $\square$ warinthorn@biotec.or.th )

National Center for Genetic Engineering and Biotechnology https://orcid.org/0000-0002-7730-6388

\section{Research}

Keywords: anaerobic digestion, GHG emission, biogas, tapioca starch

Posted Date: February 2nd, 2021

DOI: https://doi.org/10.21203/rs.3.rs-103700/v2

License: (c) (i) This work is licensed under a Creative Commons Attribution 4.0 International License. Read Full License 


\section{Abstract}

An adoption of the circular economy concept to utilize the wastes and by-products in the cassava starch industry to produce the biogas is a high potential option. Thai cassava starch industry generates wastes and by-products, as such the wastewater of 21.00 million $\mathrm{m}^{3} \mathrm{y}^{-1}$ and the cassava pulp of 9.50 million $\mathrm{t} \mathrm{y}^{-}$

${ }^{1}$. This research analyzed the key drivers and challenges to increase the demand of biogas system, increasing the energy security, resource efficiency, and decreasing the environmental problem. Threescenarios of (1) a factory has no biogas system, (2) a factory produces biogas using wastewater as a raw material, and (3) a factory produces biogas using both wastewater and cassava pulp as raw materials, were analyzed. The economic assessment, resource efficiency, water recovery, land use, and global warming potential were the parameter of comparison. Scenario 3 generated a highest net present value, and a shortest payback period for the 10-year operational period with 6.14 million USD and $4.37 \mathrm{y}$, respectively. Moreover, scenario 3 had the highest resource efficiency and water recovery with the lowest land (18.90 ha with $\left.500 \mathrm{t} \mathrm{starch} \mathrm{d}^{-1}\right)$ use and global warming (144.33 $\mathrm{kg} \mathrm{CO}_{2 \text { eq }} \mathrm{t}^{-1}$ starch).

\section{Introduction}

Application of the circular economy (CE) concept on the wastes and by-products from the cassava starch production process (CSPP) can lead to sustainable development, higher economic profit, and more efficient resource usage through waste minimization, as well as environmental benefits $[1,2]$. Cassava is an economically important tuber crop in Thailand and other ASEAN countries that is used in food, animal feed, pharmaceuticals, bioethanol, and other industries. In 2019, Thailand was the world's largest cassava starch exporter, occupying the world's market share at $80 \%$ of native cassava starch export with 2.8 million $t$ and $30 \%$ of modified cassava starch export 1.0 million $t$ [3]. The export value of native starch and modified starch was USD 2.1 billion in 2018 [4].

One ton of starch is produced from resources, i.e. approximately $4.4 \mathrm{t}$ of cassava roots, $10.9 \mathrm{~m} 3$ of water, $207.8 \mathrm{kWh}$ of electricity, 1,898.2 MJ of fuel for drying the starch, $0.9 \mathrm{~kg}$ of chemicals, and $93.1 \mathrm{~m} 3$ of biogas using in the boiler and electricity generation. Wastes from the CSPP typically consist of $0.6 \mathrm{t}$ of rhizomes, $0.17 \mathrm{t}$ of sand, $0.1 \mathrm{t}$ of cassava peels, $2.5 \mathrm{t}$ of wet pulp, $8.4 \mathrm{~m} 3$ of wastewater, and $4.0 \mathrm{~kg}$ of low-grade starch [5].

The CSPP so far adopts the CE by distributing rhizomes, sand, and peels to farmers as soil conditioner. Anaerobic wastewater treatment for biogas generation, the reuse and recycle methods are applied to the CSPP to minimize the wastewater (shown in fig. 1) [6-8]. The remaining wastewater from the CSPP is used to produce biogas to generate heat or electricity for factories with surplus electricity being sold to the grid. The wastewater has a high chemical organic content, measured as an oxygen demand (COD) level (4,800-70,000 mg L-1), high total volatile solids (1,200-39,000 mg L-1), and a low pH (4.3-5.6) [9-13]. In 2019, Thailand produced biogas from the native starch wastewater at a total amount of approximately 260.7 million $\mathrm{Nm} 3$ from 62 biogas plants [5]. 
Cassava pulp has the potential for use as a feedstock for biogas as well as an alternative for waste reduction and environmental improvement due to reducing greenhouse gas (GHG) emissions [14]. However, less than $10 \%$ of starch factories in Thailand uses cassava pulp to produce biogas due to its high lignocellulosic content. Cassava pulp consists of $60-75 \%$ starch, $4-15 \%$ cellulose, $4-5 \%$ hemicellulose, $1-3 \%$ lignin, $1-2 \%$ protein, $0.1-0.2 \%$ lipids, $2-12 \%$ ash, and $1-17 \%$ of other materials $[9,15$, 16]. Cassava pulp is currently sold as raw material for animal feed, produce cassava pellets, use as raw material for mushroom growing media, or it is sometimes given to farmers for free to use as soil conditioner at the value of 0.00-16.67 USD t-1 $[5,17]$. However, the demand of cassava pulp fluctuated depending on the factory location, nearby businesses, and/or season of the year.

Cassava pulp with high lignocellulosic materials is not extensively use for biogas production due to the limitation of digest and resist microbial hydrolysis in biogas production. Despite these limitations of commercial scale biogas production from cassava pulp are the pretreatment technology, conversion technology, and cost-effectiveness $[18,19]$. If a factory uses the pulp to produce biogas, replacing fuel oil to produce the heat and generating electricity, the values are equivalent to 11.90 and 19.28 USD t-1 of cassava pulp, respectively [5].

This research compares the benefits of adapting the CE concept to the CSPP by integrating the biogas generation system from both wastewater and solid waste as cassava pulp treatment for generation of heat and electricity. In addition, the research highlights the main drivers and barriers to implementing the part of CE concept in the CSPP in Thailand. Three scenarios are considered as follows: scenario 1 is without a biogas system in factory, scenario 2 is with biogas generation from the wastewater only, and scenario 3 is with biogas generation from both the wastewater and cassava pulp. Since scenarios 1 and 2 above are typical and well documented, this study, focused on investigating the benefits of using scenario 3.

\section{Materials And Methods}

The experimental procedures were divided into 3 sections; (1) scope and system boundary, (2) data analysis, and (3) drivers and barriers analysis. A systematic methodology to use wastewater and cassava pulp for biogas production in the starch industry (in terms of the economics, resource efficiency, water recovery, reduction of the GHG emission, and land use) were compared the benefit of adaption the part of CE concept in CSPP using cassava pulp and wastewater for biogas generation. The research framework is illustrated in fig. 2.

\subsection{Scope and system boundary}

Primary data was obtained from a native cassava starch factory in the Northeastern region of Thailand between January to December 2018. The starch production capacity was $500 \mathrm{t} \mathrm{d}^{-1}$ with 196 working d y ${ }^{-1}$. The system boundary was scoped gate-to-gate, where three new CSPP plants with the same receiving

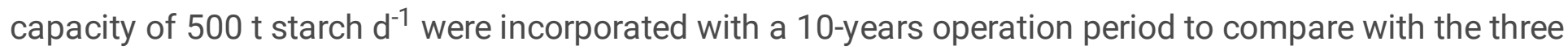


studied scenarios. The economics, resource efficiency, water recovery, reduction of GHG emissions, and land use of these three scenarios were analyzed.

\subsection{Resource efficiency and water recovery analysis}

The study aims to increase resource efficiency and water recovery including reduce electricity and fuel in CSPP. Resource consumption and waste generation (e.g., cassava root, fresh water, reuse water, recycling water, electricity, fuel oil, and biogas) was collected using daily record. The moisture content was analyzed according to the AOAC protocol [20]. Cassava pulp and wastewater were determined the starch content using solid concentration method [8]. COD was measured according to standard methods [21]. Resource and water consumption input to the process was calculated using the life cycle inventory for the three studied scenarios, and the resource efficiency and water recovery analysis was undertaken and compared between the three studied scenarios.

A case study was undertaken of a cassava factory generated $6,560 \mathrm{~m}^{3} \mathrm{~d}^{-1}$ wastewater with a COD of $12,184 \mathrm{mg} \mathrm{L}^{-1}$. The biogas production system was a covered lagoon for the wastewater treatment with $165,970 \mathrm{~m}^{3}$ in size and a retention time of $15 \mathrm{~d}$. The system yielded a COD removal efficiency of $92 \%$, achieving a COD at the outlet of $1,037 \mathrm{mg} \mathrm{L}^{-1}$ and produced $41,000 \mathrm{~m}^{3}$ biogas $\mathrm{d}^{-1}$ with a $\mathrm{CH}_{4}$ composition of $55 \%$ by volume (Figure 3 ).

In this same case study, the $450 \mathrm{t} \mathrm{d}^{-1}$ pulp was transported to the biogas plant using the thermophilic $55^{\circ} \mathrm{C}$ CSTR technology with $15 \%(\mathrm{w} / \mathrm{v})$ total solid (TS). The biogas production capacity from the pulp was $3.2 \mathrm{~m}^{3}$ biogas $\mathrm{m}^{-3}$ reactor $\mathrm{d}^{-1}$. The primary and secondary digesters were operated in series, with a buffer tank after the secondary digesters. The sediment from the buffer tank was recycled to the primary digesters to ensure the stable operation of the system and enhance the $\mathrm{CH}_{4}$ content in the biogas. The average biogas production yield was $500 \mathrm{~m}^{3} \mathrm{t}^{-1}$ TS under a hydraulic retention time of $28 \mathrm{~d}$, and yielded $22,500 \mathrm{~m}^{3}$ biogas $\mathrm{d}^{-1}$ (Figure 3 ).

\subsection{Land use analysis}

The study aims to minimize the land use for waste management. The reference for the data of land use is values taken from the factory that was used open pond for wastewater treatment during 1999 to 2005 , changed the wastewater treatment to cover lagoon in 2005 and created additional biogas system from cassava pulp in 2018.

\subsection{Environmental and economic analysis}

\subsubsection{Environmental assessment}

Environmental impact was calculated in terms of the GHG emission from the inputs of the resource usage and the outputs of the processed waste and wastewater, where the $\mathrm{GHG}$ emission was determined as the production of carbon dioxide $\left(\mathrm{CO}_{2}\right)$, methane $\left(\mathrm{CH}_{4}\right)$, and nitrous oxide $\left(\mathrm{N}_{2} \mathrm{O}\right)$. Emission factors 
used the data from the 2006 IPCC Guideline for National Greenhouse Gas Inventories and Thailand Greenhouse Gas Management Organization [22, 23]. The $\mathrm{CO}_{2}$ emissions from the wastewater and cassava pulp digestion in an anaerobic digestion system were not considered here as these are of biogenic origin. Assessment of the $\mathrm{CH}_{4}$ and $\mathrm{N}_{2} \mathrm{O}$ production potential was based on the concentration of degradable organic matter in the wastewater and cassava pulp. Further emissions released from the biogas combustion to produce heat and electricity, as well as emissions from resource usage were input to the process.

Air emission such as $\mathrm{CO}_{2}, \mathrm{CH}_{4}, \mathrm{NO}_{x}$, etc. from fuel combustion was calculated from Eq. (1);

Air emission $=\Sigma\left(x \mathrm{EF}_{\mathrm{i}}\right)$

where subscript $Q_{i}$ is the quantity of fuel type $i\left(T J F U^{-1}\right)$ and $E F$ is the emission factor of fuel type $i(k g$ pollutant $\left.\mathrm{TJ}^{-1}\right)$.

In addition, the general equation to estimate $\mathrm{CH}_{4}$ generation from CSPP wastewater was calculated from Eq. (2);

$\mathrm{CH}_{4}$ generation $(\mathrm{kg} / \mathrm{FU})=\Sigma\left[(\mathrm{TOW}-\mathrm{S}) \times \mathrm{B}_{\mathrm{O}} \times \mathrm{MCF}-\mathrm{R}\right]$

where TOW is the total organic degradable material in wastewater $\left(\mathrm{kg} \mathrm{COD} \mathrm{FU}^{-1}\right), \mathrm{S}$ is an organic component removed as sludge $\left(\mathrm{kg} \mathrm{COD} \mathrm{FU}^{-1}\right), \mathrm{B}_{\mathrm{O}}$ is a maximum $\mathrm{CH}_{4}$ producing capacity $\left(0.25 \mathrm{~kg} \mathrm{CH}_{4} \mathrm{~kg}^{-1}\right.$ COD), MCF is the methane correction factor, and $\mathrm{R}$ is the amount of $\mathrm{CH}_{4}$ recovered to the energy source $\left(\mathrm{kg} \mathrm{CH}_{4} \mathrm{FU}^{-1}\right)$.

\subsubsection{Economic impact}

The calculations of the net present value (NPV), internal rate of return (IRR), and payback period were based on a 10-years operation period with the capital and operating costs calculated as the total production cost [24]. According to the scenario, the first year of operation included the major financial investment. The capital cost included land use, buildings, machinery, and equipment. The operating costs consisted of materials, labor, social fund, tax fund, and depreciation. The material cost was calculated from the price of direct materials for manufacturing.

The NPV was used to calculate the value of the future project in terms of the present value. The NPV of the investment project was calculated from Eq. (3);

$$
\mathrm{NPV}=\sum_{t=1}^{T} \frac{C_{t}}{(1+r)^{t}}-C_{0}
$$


where $C_{t}$ is the net cash inflow during the period $t, C_{o}$ is the total initial investment cost, $r$ is the discount rate, and $t$ is the number of time periods.

The IRR is used to evaluate the desirability of an investment or project. The higher the IRR on a project, the more desirable it is to undertake the project. The IRR was calculated from Eq. (4),

$$
0=\sum_{t=1}^{T} \frac{C_{t}}{(1+\mathrm{IRR})^{t}}
$$

The payback period (PBP) is the period of time required to recoup the funds expended in the investment and was calculated from Eq. (5);

$$
\text { PBP }=\frac{\text { Cost of investment }}{\text { Annual cash inflow }}
$$

\subsection{Drivers and barriers to applying the CE concept in the Thai CSPP}

The drivers and barriers to implementation of the CE concept were analyzed from surveys, interviews, and questionnaires of twelve cassava starch factories. Four of these factories applied biogas production from cassava pulp under the CE concept.

\section{Results And Discussion}

\subsection{Resource efficiency analysis}

\subsubsection{Analysis of water consumption and wastewater generation}

For each ton of cassava starch, the freshwater consumption within the starch production process in scenario 1 used $16.7 \mathrm{~m}^{3}$ of freshwater and generated $19.6 \mathrm{~m}^{3}$ of effluent as show in table 1 and figure 3 . The wastewater enters the open lagoon for evaporation. To minimize wastewater sources, wastewater from each processing unit can be reused or recycled based upon its characteristics in the former units, e.g., wastewater from the separating and dewatering units were reused to the extracting and separating unit. The used water from the dewatering unit contained protein impurities and so was not suitable to be reused in the other stages except for root washing $[8,25]$. For scenario 2 , the freshwater consumption (per ton of cassava starch) was $15.1 \mathrm{~m}^{3}$ of freshwater and $1.6 \mathrm{~m}^{3}$ of recycled water, generating $19.6 \mathrm{~m}^{3}$ of effluent. The wastewater entered the covered lagoon to generate $59.3 \mathrm{~m}^{3}$ of biogas. For scenario 3 , the water consumption was $15.1 \mathrm{~m}^{3}$ of freshwater and $1.6 \mathrm{~m}^{3}$ of recycled water to generate $17.6 \mathrm{~m}^{3}$ of effluent. The wastewater entered the covered lagoon to generate $357.8 \mathrm{~m}^{3}$ biogas as show in figure 3 . 
The biogas from scenario $\mathbf{2}$ and $\mathbf{3}$ used to producing heat and electricity in the CSPP. The treated wastewater was discharged into the open lagoon. The factory distributed the treated wastewater for nearby farmers to use as liquid fertilizer [25].

\subsubsection{Analysis of energy consumptions}

The electricity consumption of the CSPP was calculated as $197.8 \mathrm{kWh} \mathrm{t}^{-1}$ of starch. For scenario 2, 4.5 $\mathrm{kWh} \mathrm{t}^{-1}$ cassava starch produced was required for the biogas system from wastewater, whereas in scenario 3 this was almost 2.6 -fold higher at $11.6 \mathrm{kWh} \mathrm{t}^{-1}$ the CSPP as shown in table 1 . However, the biogas obtained from the wastewater produced $21.2 \mathrm{kWh}$ of electricity or $2.54 \mathrm{USD} \mathrm{t}^{-1}$, while the biogas production from cassava pulp produced $968.9 \mathrm{kWh}$ of electricity and then be used in the CSPP $176.6 \mathrm{kWh}$ or 21.19 USD t $^{-1}$ of starch. Therefore, a surplus of $738.4 \mathrm{kWh}$ from scenario 3 was generated and could theoretically be sold to the electricity grid as 88.60 USD t $^{-1}$ of starch as show in table 1 and figure 3 .

The fuel oil used to supply process heat for the flash dryer was evaluated as 1,518.5 MJ. Biogas recovery from the wastewater treatment system has shown great potential for starch factories. Since the price of

fuel oil has increased significantly over the past decade, cassava starch factories have been using biogas to replace the fuel oil for the burners to generate hot air for drying the moist starch. The direct burning of the biogas obtained from the wastewater can supply 1,124.2 $\mathrm{MJ}$ of energy. Moreover, the biogas from scenario 3 is able to supply 1,724.2 MJ of energy as show in table 1. In conclusion, the fuel oil is unnecessary for thermal energy in the CSPP. The recovered biogas from the wastewater and cassava pulp was used to substitute fuel oil of 29.4 and $15.7 \mathrm{~L} \mathrm{t}^{-1}$ of starch and this helped to reduce the fuel cost by approximately 16.49 and 8.80 USD t $^{-1}$ of starch, respectively, based upon the cost of fuel oil at 0.56 USD $L^{-1}$ as show in table 1 and figure 3 .

\subsubsection{Cost reduction}

The main production cost in the CSPP is the expenditure on purchasing cassava roots, which makes up to $83-91 \%$ of the total costs. The other costs are electricity (3-9\%), fuel (4-5\%), water (1\%), chemicals (4\%), and labor (2\%) [8]. In this case, the reduction in the fuel oil and electricity from biogas in scenarios 2 and 3 reduced the total costs by $4 \%$ and $11 \%$, respectively as show in figure 3 .

The scenario 3 has the highest resource efficiency because the conversion of the waste into a biogas (value-added product). Therefore, the electricity and fuel in CSPP was reduced due to the substitution of the energy source by biogas.

\subsection{Environmental impact assessment}

The CE concept focuses on reducing the landfill, GHG emission, and production energy consumption, while increasing the resource use efficiency and so enabling a new life-cycle for the otherwise end-of-life product. Regarding the minimization of the $\mathrm{GHG}$ emissions, the $\mathrm{CO}_{2}$ equivalent from the three scenarios 
was considered in this study to analyze the GHG emission. From the previous study found that the total GHG emission of cassava starch production was in the range $93.2-935.0 \mathrm{~kg} \mathrm{CO}_{2 \mathrm{eq}} / \mathrm{FU}[14,26]$.

In this study, the GHG emission was related to the emissions from electricity consumption, energy consumption, cassava pulp utilization options, and water treatment methods. The CSPP contributed 144.3-636.0 $\mathrm{kg} \mathrm{CO}_{2 \text { eq }} \mathrm{t}^{-1}$ (Table 1). Key factors of variations were used different total amounts of electricity, fuel, and water (fresh and recycle water). In the no biogas scenario, the GHG emission of CSPP was higher 3-4 times than that in the biogas scenario because of the higher emissions of methane to atmosphere from the wastewater, the emissions of fossil fuel during combustion, and the higher use of grid electricity. These results mean the GHG emission of CSPP in Thailand was reduced from 2.4 million $t$ of $\mathrm{CO}_{\text {2eq }} \mathrm{y}^{-1}$ to 0.6-0.8 million $\mathrm{t}$ of $\mathrm{CO}_{2 \text { eq }} \mathrm{y}^{-1}$.

Under scenario 3, the cassava starch industry applied the CE concept, including a covered lagoon for biogas generation from wastewater and a CSTR for biogas generation from the cassava pulp, reducing the GHG emission by $77 \%$ as shown in figure 4 . This result was achieved by the reduced electricity consumption from the electricity grid and the reduced GHG emission from wastewater treatment using anaerobic technology.

\subsection{Land use}

The three scenarios were also examined for their effect on the land utilization. For a cassava starch factory with a process capacity of $500 \mathrm{t} \mathrm{d}^{-1}$, the land use options are the construction of a 1.6 ha starch production plant, 14.5 ha wastewater treatment (covered lagoon), 1.8 ha CSTR for biogas production from cassava pulp, and 44.3 ha for drying the cassava pulp. The total land use areas for scenarios 1,2 , and $\mathbf{3}$ were $59.2,47.2$, and 18.9 ha, respectively. The land needs are significantly reduced for scenario 3 due to the reduction of the cassava pulp drying area and open pond for wastewater treatment.

\subsection{Economic impact}

The economic viability and the IRR are the main factors of concern to any entrepreneur, and the first stage that entrepreneurs will calculate is total investment cost. The investment cost of a biogas system depends on type of feedstock and biogas conversion technology. The relationship between the investment time and biogas conversion technology providesa measurement of the corresponding effect in terms of investment timing. For this, the NPV is the economic analysis method that best assesses the investment cost of a biogas system.

As outlined already, cassava pulp can be utilized in many ways, such as the animal feed, and a carbon source in an alcohol fermentation process. However, the factories are not entirely satisfied with the current cassava pulp utilization and disposal options because the cassava pulp still has high starch content, which they view as a loss to them, even though odor is a constant problem. Biogas generation from cassava pulp is one option to solve these problems $[5,16]$. 
The investment cost varied with the size of reactor and the organic loading rate to the system $\left(\mathrm{kg} \mathrm{COD} \mathrm{m}^{3}\right.$ of digester $\mathrm{d}^{-1}$ ). The investment and operation costs of the CSTR technology were 180.00-267.00 USD m-3 biogas system and 0.07-0.17 USD $\mathrm{m}^{-3}$ wastewater, respectively [19]. In this study, the investment cost of the biogas production system consisted of land (10-25\%), reactor system (18-35\%), piping (5-13\%), purification system (8-12\%), generator (15-29\%), and other (e.g., insulation and equipment installation). The key economic indicators for a biogas system from wastewater and cassava pulp are presented in Table 2. For the biogas generation from scenarios 2 and $\mathbf{3}$, the total investment cost was 2.24 and 8.65 million USD, respectively. The payback period for biogas generation from scenario 3 was the most economically attractive option due to the highest NPV of 6.15 million USD with a payback period of 4.37 y.

\subsection{Drivers and barriers of CE concept implementation for the CSPP}

This study determined which four main factors that were technical, economic, regulatory, and social responsibility as a driver or a barrier for CE concept implementation in the CSPP. A driver was defined as a supporting factor and a barrier was defined as an inhibiting factor to implementation of the CE concept using the wastewater and cassava pulp to produce biogas for producing heat and electricity in factories.

The results showed that the main driver and barrier for CE concept implementation in the CSPP were technical concerning. The regulatory factors were the most important concern to entrepreneurs (36\%), followed closely by economic factors (35\%) and then social responsibility and technical support at 21 and $8 \%$, respectively. For the barriers to CE concept implementation technical problems were the most important factor that concerned entrepreneurs (35\%), followed by regulatory, economic, and social at $23 \%, 22 \%$, and $20 \%$, respectively $[27,28]$. The driver and barrier of CE concept implementation are as show in table 3.

\subsubsection{Technology}

The technical barriers are outlined in turn below.

\subsubsection{Limitations of pretreatment technology}

The application of biogas production from cassava pulp still has technical and cost-effectiveness limitations. Technically, the cassava pulp has high lignocelluloses so these are difficult to convert into biogas. It requires both a long retention time inside the biogas reactor and an equally large reactor size $[19,29]$. The pretreatment process to increasing surface area of cassava pulp, increasing microorganism accessibility, increasing substrate digestibility, and increasing lignin and hemicellulose solubility might be required $[13,30]$. Currently, the total degradation time for the solid organic waste is approximately $30 \mathrm{~d}$.

\subsubsection{Availability of cassava pulp}

The amount of energy produced from biogas varies with the volume of cassava pulp generated by the factory, making it difficult to manage the energy. Cassava pulp is an agricultural residue that is available 
only during the cassava root harvesting period (September to April), is difficult to store, and so it is sometimes left on the biogas generation site for mulching purposes [29]. Biogas production systems that support a wide range of raw materials and substrates would enhance the investment opportunities for biogas production systems and satisfy the desire of the electricity utility for year-round generation. More work needs to be done on developing such systems.

\subsubsection{Lack of a successful model for biogas production from cassava pulp}

A modified covered lagoon is the most popular system chosen by investors for processing cassava pulp due to the stability of the system. Furthermore, the system is able to support the fluctuation/variance of wastewater/solid waste in each production season, does not have a very high investment cost and is relatively easy for operation and maintenance. Yet the system requires large land area. However, most starch factories are not confident in the efficiency of the high technology for biogas system generation from cassava pulp, since the technology has not yet been established the commercial scale, nor shown to be cost-effective. Too few models of success to establish the efficiency of this biogas technology are available to satisfy the doubts of potential investors.

\subsubsection{Economic}

Economic barriers to CE concept implementation for the CSPP are related to the cost-effectiveness, uncertain return and profit, and lack of incentive.

\subsubsection{Financial barriers}

The biogas investment and operation cost was approximately 6.00-1000.00 USD $\mathrm{m}^{-3}$ and 0.02-2.67 USD $\mathrm{m}^{-3}$ of wastewater respectively, ranging from a simple lagoon to high technology biogas system with pretreatment technology. It can be seen that the more complex the technology, the higher the operating cost. The cost depends not only on the chosen technology, but also the type of feedstock [19, 30]. Therefore, biogas production from the cassava pulp requires a pretreatment step to adjust the physical and chemical properties, which results in higher biogas production costs and investment costs.

Current benefit measures provided by the government, such as tax benefits and financial support, are too little to motivate entrepreneurs to invest more in building biogas systems. Added to this is the difficulty of paperwork when requesting funding for an extension of the support limit, for permits, and for licenses, which often involve different agencies. Thus, the associated bureaucracy needs to be made easier.

\subsubsection{Lack of incentive}

Government policies, especially the announcement to stop accepting claims and proposals to sell electricity from very small power producers that generate electricity from RE, is causing a slowdown in investment and is of great concern to the entrepreneurs who have already invested in biogas power generation systems. In addition, the current electricity purchase price is close to the production cost, making the PBP longer, and so far less attractive for the private sector to invest in. This is because the 
Ministry of Energy estimates that current electricity reserves are about 30\% [31]. The termination of financial assistance, especially for the cases of waste and wastewater without efficient technology, is a major obstacle causing the private sector to cancel or delay the decision to invest in biogas production systems. Although there is an overall policy to promote energy from renewable resources, the denial of new feed-in tariff (FiT) approvals is possibly the greatest barrier to investment. It not only denies an increase in the use of renewable resources, it runs counter to CE concept implementation.

\subsubsection{Regulatory}

Environmental regulations are one of the drivers of CE concept implementation for the CSPP related to the reduction of GHG emission. Since laws require expensive policing and civil actions, voluntary compliance under social responsibility would be preferable [32].

\subsubsection{Agreement on $G H G$ emissions in COP24}

From COP24, Thailand signed an agreement on the implementation of the guidelines of the Paris Agreement to reduce its GHG emission by $20 \%$ below the 2010 emission levels by 2030 . Environmental policies have been set up, such as the Environmentally Sustainable Transport System Plan, a Waste Management Roadmap, FiT, and tax incentives, to promote investment in RE [31, 32].

\subsubsection{Laws on waste and wastewater treatment}

Hazardous Waste Management laws define cassava pulp as a hazardous waste so it is prohibited to transport it off-site. This results in the disturbing odors and the need for landfill for drying the cassava pulp.

In terms of barriers, the primary disincentives are the high initial investment costs, lack of a conducive legal system, limited government support, especially in power purchase and production of RE, as well as a conflict in the laws on waste management and product lifecycle management. These are outlined in turn below.

\subsubsection{Lack of a conducive legal system}

The government attaches great importance to the development of the country into the CE. However, this top down policy has not been integrated into the actual production stream with any unity. By way of example, investment in biogas systems still requires contacting several departments, either sub-district administration organizations, provincial industry authorities, Department of Industry, Department of Business Development, Department of Alternative Energy Development and Energy Conservation, local power authorities, local environment authorities, and the Energy Regulatory Office.

\subsubsection{Limited government support}

Policy/law/regulation in RE and the environment is unclear and highly changeable in biogas production systems. Thailand has the policies and strategies in place associated with a sustainable development, 
environment, and energy, including the implementation of the Sustainable Development Agenda B.E. 2030, (Sustainable Development Goals: SDGs), the AEDP was updated in 2018 to focus on bio, circular, and green economy [31]. However, the various promotional measures focus on the economic returns and determination of the purchase price of RE is mainly based on the lowest cost of energy.

\subsubsection{Conflict of laws on waste management on product lifecycle management}

The Urban Planning Act stipulates that biogas projects are on a negative list and so cannot be co-located with raw material production sources (e.g., cassava starch factories and palm oil plants). Currently, the Ministry of Industry is in the process of listening to public opinion to solve this issue of the urban plan problem as it is also associated with the request for borrowing funds from the bank by the developer.

\subsubsection{Social responsibility}

Social responsibility is driven by CE concept implementation in the cassava starch industry related to the area of the industry. These are discussed below

\subsubsection{Expansion of communities close to industry}

With the high demand for living space, communities are expanding closer to the cassava processing factories, which, when first established, were relatively isolated. This is largely due to a lack of proper zoning from the outset. Communities are of course concerned about the detrimental environmental effects of industry and are active in their surveillance and reporting to the government. This result in an important driving force for investment in the CE concept and minimization of emissions and waste.

The current barriers are associated with the lack of environmental concern from entrepreneurs.

\subsubsection{Lack of environmental concern}

Thailand's environmental laws have only been set for sewage measures. Therefore, entrepreneurs are not interested in investing in high-efficiency biogas production systems that require a high investment. This is in contrast to foreign countries, such as Germany and Italy, who have implemented measures to support/attract the use of more modern technology.

Therefore, Thailand should establish a network, including the enforcement of environmental laws, and improve related laws to be in the same direction. Environmental crime punishment, surveillance, and reporting are important driving forces for investment in biogas production systems. This would include the establishment of an organization to disseminate knowledge, including making policy recommendations that promote and support the construction of biogas production systems in accordance with space and industry limitations. In addition, for effective operations, the government needs to establish a mechanism for monitoring and disseminating biogas performance to the public.

\section{Conclusions}


The purpose of this study was to apply the part of circular economy concept implementation for the cassava starch production process by using cassava pulp and wastewater to biogas production. This study focused on three scenarios are considered as follows: scenario 1 is without a biogas system in factory, scenario 2 is with biogas generation from the wastewater only, and scenario 3 is with biogas generation from both the wastewater and cassava pulp. The most economically and environmental attractive utilization was the scenario 3 , which provided the highest net present value per 10-year operational period (6.14 million USD) and the lowest payback period (4.37 y) with the lowest greenhouse gas emission with $144.33 \mathrm{~kg} \mathrm{CO}_{2 \text { eq }} \mathrm{t}^{-1}$. The advantages of these implementation attempt to increase energy security and resource efficiency and decrease the problems of waste management including reduce disturbing odor, the waste entering landfills, greenhouse gas emissions, and land use. However, the barriers to biogas production from cassava pulp are cost and technology for pretreatment of the cassava pulp. Supportive regulatory and financial support mechanisms are needed for an investor to progress from the early business-planning stages through to operations and commercial sustainability.

\section{Declarations}

\section{Availability of data and materials}

The datasets used and/or analyzed during the current study are available from the corresponding author on reasonable request. The necessary data that generated and analyzed during this study are included in this published article and its supplementary information file.

\section{Competing interests}

The authors declare that they have no competing interests.

\section{Funding}

This work was supported by the Joint Graduate School of Energy and Environment (JGSEE), King Mongkut's University of Technology Thonburi and the Center of Excellence on Energy Technology and Environment (CEE), PERDO, Ministry of Higher Education, Science, Research and Innovation, Thailand (grant number: JGSEE/THESIS/262, 2016).

\section{Authors' contribution}

Songkasiri, W. designed, directed, and coordinated for this research. Songkasiri, W. and Phalakornkule, C. provided conceptual and technical guidance for all aspect of the project. Lerdlattaporn, R. and Trakulvichean, S. performed and analyzed the data of economic assessment, resource efficiency, water recovery, land use, and global warming potential for using wastewater and cassava pulp for biogas production in the cassava starch industry in Thailand. Lerdlattaporn, R. wrote the manuscript. Songkasiri, W. and Phalakornkule, C. commented, reviewed, edited, and approved for its completion.

\section{Acknowledgements}


The authors express their gratitude to the Joint Graduate School of Energy and Environment (JGSEE), King Mongkut's University of Technology Thonburi and the Center of Excellence on Energy Technology and Environment (CEE), PERDO, Ministry of Higher Education, Science, Research and Innovation, Thailand for the financial support provided to perform this study.

\section{References}

1. Geissdoerfer M, Savaget P, Bocken NM, Hultink EJ. The Circular Economy-A new sustainability paradigm? J Clean Prod. 2017; doi:10.1016/j.jclepro.2016.12.048.

2. Morseletto P. Targets for a circular economy. Resour Conserv Recycl. 2020; doi: 10.1016/j.resconrec.2019.104553

3. Krungsri Research. Cassava Industry. 2020. https://www.krungsri.com/bank/getmedia/cf2d388d4fdb-48a4-8196-89aef2e5f86d/IO_Cassava_200511_EN_EX.aspx. Accessed 20 Nov 2020.

4. Thai Customs Department. Export Tapioca Product. 2020. http://www.thaitapiocastarch.org/th/information/statistics/ Accessed 20 Nov 2020.

5. Trakulvichean S, Chaiprasert P, Otmakhova J, Songkasiri W. Integrated economic and environmental assessment of biogas and bioethanol production from cassava cellulosic waste. Waste Biomass Valor. 2019; doi:10.1007/s12649-017-0076-x.

6. Dakwala M, Mohanty B, Bhargava R. Waste water minimization of starch industry using water pinch technology. In: 3th International Workshop for Advances in Cleaner Production. Brazil; 2011 May 1820.

7. Yesaswini G, Saravanathamizhan R. Wastewater Minimization of Starch Industry using Water Pinch Analysis and Comparison with Water Design Software. Int J Sci Res Sci Eng Technol. 2018;4(4):659-63.

8. Songkasiri W, Nopharatana A, Seangchan K, Ruttithiwapanich T, Chayawattana T, Lerdlattaporn R, et al. Productivity and Process Efficiency Improvement of Tapioca Starch Industry. 2014. http://www.thailandtapiocastarch.net/download/download-th-55. Accessed 20 Nov 2020 [in Thai].

9. Chavalparit O, Ongwandee M. Clean technology for the tapioca starch industry in Thailand. Clean. Prod. 2009; doi:10.1016/j.jclepro.2008.03.001.

10. Colin X, Farinet JL, Rojas O, Alazard D. Anaerobic treatment of cassava starch extraction wastewater using a horizontal flow filter with bamboo as support. Technol. 2007; doi:10.1016/j.biortech.2006.06.020.

11. Sun L, Wan S, Yu Z, Wang Y, Wang S. Anaerobic biological treatment of high strength cassava starch wastewater in a new type up-flow multistage anaerobic reactor. Bioresour Technol. 2012; doi:10.1016/j.biortech.2011.11.070.

12. Wang W, Xie L, Chen J, Luo G, Zhou Q. Biohydrogen and methane production by co-digestion of cassava stillage and excess sludge under thermophilic condition.Bioresour Technol. 2011; doi:10.1016/j.biortech.2010.12.012. 
13. Zhang Q, He J, Tian M, Mao Z, Tang L, Zhang J, Zhang H. Enhancement of methane production from cassava residues by biological pretreatment using a constructed microbial consortium. Bioresour Technol. 2011; doi: 10.1016/j.biortech.2011.06.061.

14. Hansupalak N, Piromkraipak P, Tamthirat P, Manitsorasak A, Sriroth K, Tran T. Biogas reduces the carbon footprint of cassava starch: a comparative assessment with fuel oil. J Clean Prod. 2016; doi:10.1016/j.jclepro.2015.06.138.

15. Virunanon C, Ouephanit C, Burapatana V. Cassava pulp enzymatic hydrolysis process as a preliminary step in bio-alcohols production from waste starchy resources. J Clean Prod. 2013; doi:10.1016/j.jclepro.2012.07.055.

16. Sriroth K, Chollakup R, Chotineeranat S. Processing of cassava waste for improved biomass utilization. Bioresour Technol. 2000; doi:10.1016/S0960-8524(99)00051-6.

17. Sivamani S, Chandrasekaran AP, Balajii M, Shanmugaprakash M, Hosseini-Bandegharaei A, Baskar $\mathrm{R}$, Evaluation of the potential of cassava-based residues for biofuels production. Rev. Environ Sci Biotechnol. 2018; doi:10.1007/s11157-018-9475-0.

18. Jeihanipour A. Waste textiles bioprocessing to ethanol and biogas [Ph.D. Dissertation]. Chalmers Univ of Technol. 2011. https://www.diva-portal.org/smash/get/diva2:876979/FULLTEXT01.pdf. Accessed 17 Dec 2020.

19. Department of Industrial Works. Manual on Process Design, Quality Control, and Operation Process of Biogas System for Industrials. 2010. https://www.diw.go.th/km/safety/pdf/biogas_2.pdf. Accessed 17 Dec 2020 [in Thai].

20. Official method of analysis. 16th ed. Virginia: AOAC International; 1995.

21. Standard Methods for the Examination of Water and Wastewater. 20th ed. Washington, DC: American Public Health Association; 1998.

22. 2006 IPCC guidelines for national greenhouse gas inventories (Vol.5). Institute for Global Environmental Strategies; 2006.

23. Greenhouse Gas Management Organization. Emission Factor in Thailand. 2019. http://thaicarbonlabel.tgo.or.th/admin/uploadfiles/emission/ts_11335ee08a.pdf. Accessed 3 Dec 2020.

24. Jovanović P. Application of sensitivity analysis in investment project evaluation under uncertainty and risk. Int J Project Manag. 1999; doi:10.1016/S0263-7863(98)00035-0.

25. Sánchez AS, Silva YL, Kalid RA, Cohim E, Torres EA. Waste bio-refineries for the cassava starch industry: New trends and review of alternatives. Renew Sust Energ Rev. 2017; doi:10.1016/j.rser.2017.02.007.

26. Tran T, Da G, Moreno-Santander MA, Vélez-Hernández GA, Giraldo-Toro A, Piyachomkwan K, Sriroth $\mathrm{K}$, Dufour D. A comparison of energy use, water use and carbon footprint of cassava starch production in Thailand, Vietnam and Colombia. Resour Conserv Recycl. 2015; doi:10.1016/j.resconrec.2015.04.007. 
27. Sousa-Zomer TT, Magalhães L, Zancul E, Cauchick-Miguel PA. Exploring the challenges for circular business implementation in manufacturing companies: An empirical investigation of a pay-per-use service provider. Resour Conserv Recycl. 2018; doi:10.1016/j.resconrec.2017.10.033.

28. Vanner R, Bicket M, Withana S, Brink PT, Razzini P, Dijl EV, et al. Scoping study to identify potential circular economy actions, priority sectors, material flows and value chains. European Commission. 2014. doi: $10.2779 / 29525$

29. Cannemi M, García-Melón M, Aragonés-Beltrán P, Gómez-Navarro T. Modeling decision making as a support tool for policy making on renewable energy development. Energy Pol. 2014; doi:10.1016/j.enpol.2013.12.011.

30. Zheng Y, Zhao J, Xu F, Li Y. Pretreatment of lignocellulosic biomass for enhanced biogas production. 2014; doi:10.1016/j.pecs.2014.01.001.

31. Department of Alternative Energy Development and Efficiency. Department of Alternative Energy Development and Efficiency Plan 2018. 2019. http://www.greennetworkthailand.com/\%E0\%B8\%9E\%E0\%B8\%9E\%E0\%B8\%AA\%E0\%B8\%99\%E0\%B8\%9E-aedp- Accessed 3 Nov 2020 [in Thai].

32. Evans S, Timperley J. COP24: Key outcomes agreed at the UN climate talks in Katowice. In: Carbon Brief. 2018. https://www.carbonbrief.org/cop24-key-outcomes-agreed-at-the-un-climate-talks-inkatowice. Accessed 18 Dec 2020

\section{Tables}

Table 1. The resource usage, waste generation, GHG emission, and land use of the Thai CSPP (per one ton of cassava starch produced). Three scenarios of starch production consist of (1) scenario 1, before applying the CE concept without biogas system in factory, (2) scenario 2, with biogas generation from wastewater, and (3) scenario 3, with biogas generation from wastewater and cassava pulp. 
Scenario Scenario Scenario 3

12

\section{Resource usage}

Cassava root (t dry basis)

1.56

1.56

1.56

Fresh water $\left(\mathrm{m}^{3}\right)$

$16.7 \quad 15.1$

15.1

Chemical (kg)

0.26

0.26

0.66

Recycled water $\left(\mathrm{m}^{3}\right)$

0.00

1.57

4.45

Biogas production $\left(\mathrm{m}^{3}\right)$

0.00

59.32

357.70

Electricity from grid (kWh)

$197.80 \quad 176.60$

0.00

Electricity from biogas (kWh)

$0.00 \quad 21.20$

197.80

(Surplus:738.40)

Fuel oil consumption (L)

45.15

15.71

0.00

Biogas for drying $\left(\mathrm{m}^{3}\right)$

0.00

64.45

98.84

Waste generation

Wastewater to final open lagoons $\left(\mathrm{m}^{3}\right)$

19.18

14.73

17.61

COD of wastewater to final open lagoons $12,184.00 \quad 715.00$

715.00

$(\mathrm{mg} / \mathrm{L})$

Cassava pulp (t dry basis)

$1.55 \quad 1.55 \quad 1.01$

Peel (t dry basis)

0.05

0.05

0.05

Rhizome (t dry basis)

0.53

0.53

0.53

Sand/soil (t dry basis)

0.40

0.40

0.40

GHG emission

Wastewater $(\mathrm{kg} \mathrm{CO} 2 \mathrm{eq})$

398.67

15.74

15.74

Cassava pulp fermentation

0.71

0.71

0.47

$\left(\mathrm{kg} \mathrm{CO} \mathrm{CO}_{2 \mathrm{q}}\right)$

Electricity consumption in biogas system (kg

0.15

19.93 $\mathrm{CO}_{2 \mathrm{eq}}$ ) 


\begin{tabular}{|c|c|c|c|}
\hline & $\begin{array}{c}\text { Scenario } \\
1\end{array}$ & $\begin{array}{c}\text { Scenario } \\
2\end{array}$ & Scenario 3 \\
\hline $\begin{array}{l}\text { Electricity consumption in cassava starch } \\
\text { production } \\
\left(\mathrm{kg} \mathrm{CO} \mathrm{CO}_{2 \mathrm{eq}}\right)\end{array}$ & 115.15 & 106.36 & 33.26 \\
\hline $\begin{array}{l}\text { Thermal consumption in biogas system (kg } \\
\left.\mathrm{CO}_{2 \text { eq }}\right)\end{array}$ & - & - & $\begin{array}{l}0.00 \\
\left(3 \times 10^{-3}\right)\end{array}$ \\
\hline $\begin{array}{l}\text { Thermal consumption in cassava starch } \\
\text { production } \\
\left(\mathrm{kg} \mathrm{CO}_{2 \mathrm{eq}}\right)\end{array}$ & 121.42 & 89.64 & 74.93 \\
\hline Total (kg CO $\left.\mathrm{CO}_{2 \mathrm{eq}}\right)$ & 635.95 & 212.62 & 144.33 \\
\hline Land use (ha) & 59.22 & 47.18 & 18.90 \\
\hline
\end{tabular}

Table 2. Key indicators of different biogas technologies

\begin{tabular}{llcc}
\hline Key indicator & Unit & $\begin{array}{c}\text { Biogas from } \\
\text { wastewater }\end{array}$ & $\begin{array}{c}\text { Biogas from wastewater and cassava } \\
\text { pulp }\end{array}$ \\
\hline Discount rate & $\%$ & 10.00 & 10.00 \\
Investment & Million & 2.24 & 8.65 \\
cost & USD & & \\
(First year) & & 1.98 & 6.14 \\
NPV & Million & & \\
& USD & 18.00 & 31.00 \\
IRR & $\%$ & 5.03 & 4.37 \\
PBP & Year & & \\
\hline
\end{tabular}

Table 3. Drivers and barriers for the CE concept implementation of the Thai CSPP 


\begin{tabular}{|c|c|c|c|c|}
\hline & Technology & Economic & Regulatory & $\begin{array}{l}\text { Social } \\
\text { responsibility }\end{array}$ \\
\hline Oriver & & & $\begin{array}{l}\text { - Agreement on COP } 24 \\
\text { for GHG emission } \\
\text { reduction to } 20 \% \text { below } \\
\text { the business as usual by } \\
2030 \\
\text { - Laws on waste and } \\
\text { wastewater treatment }\end{array}$ & $\begin{array}{ll}\text { Expansion of } \\
\text { community } \\
\text { close } \\
\text { industry }\end{array}$ \\
\hline 3arrier & $\begin{array}{l}\text { Availability of } \\
\text { - pulp } \\
\text { cassava for } \\
\text { (technology slexible substrate) }\end{array}$ & $\begin{array}{l}\text { - Financial } \\
\text { barriers from } \\
\text { investment } \\
\text { cost } \\
\text { effectiveness } \\
\text { - Lack of } \\
\text { incentive }\end{array}$ & $\begin{array}{l}\text { - Conflict of laws on } \\
\text { waste management and } \\
\text { product lifecycle } \\
\text { management } \\
\text { - Lack of a conductive } \\
\text { legal system }\end{array}$ & $\begin{array}{l}\text { Lack of } \\
\text { environmental } \\
\text { concern }\end{array}$ \\
\hline & $\begin{array}{ll}\text { - Lack of a } & \text { of } \\
\text { successful } & \text { model } \\
\text { for } & \text { biogas } \\
\text { production } & \text { from } \\
\text { cassava pulp }\end{array}$ & & $\begin{array}{l}\text { - Limited government } \\
\text { support }\end{array}$ & \\
\hline
\end{tabular}

Figures 


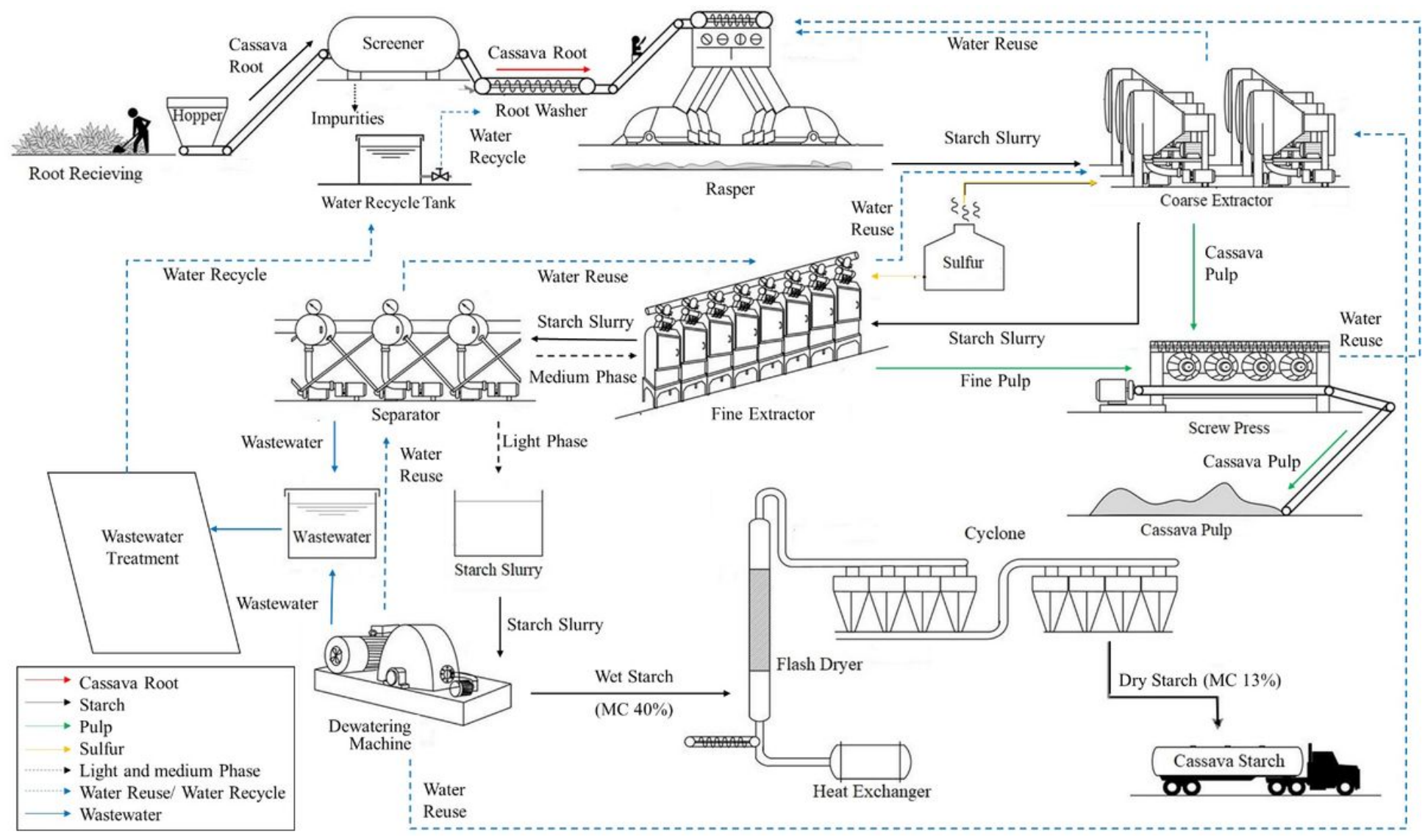

\section{Figure 1}

Schematic diagram summarizing the CSPP

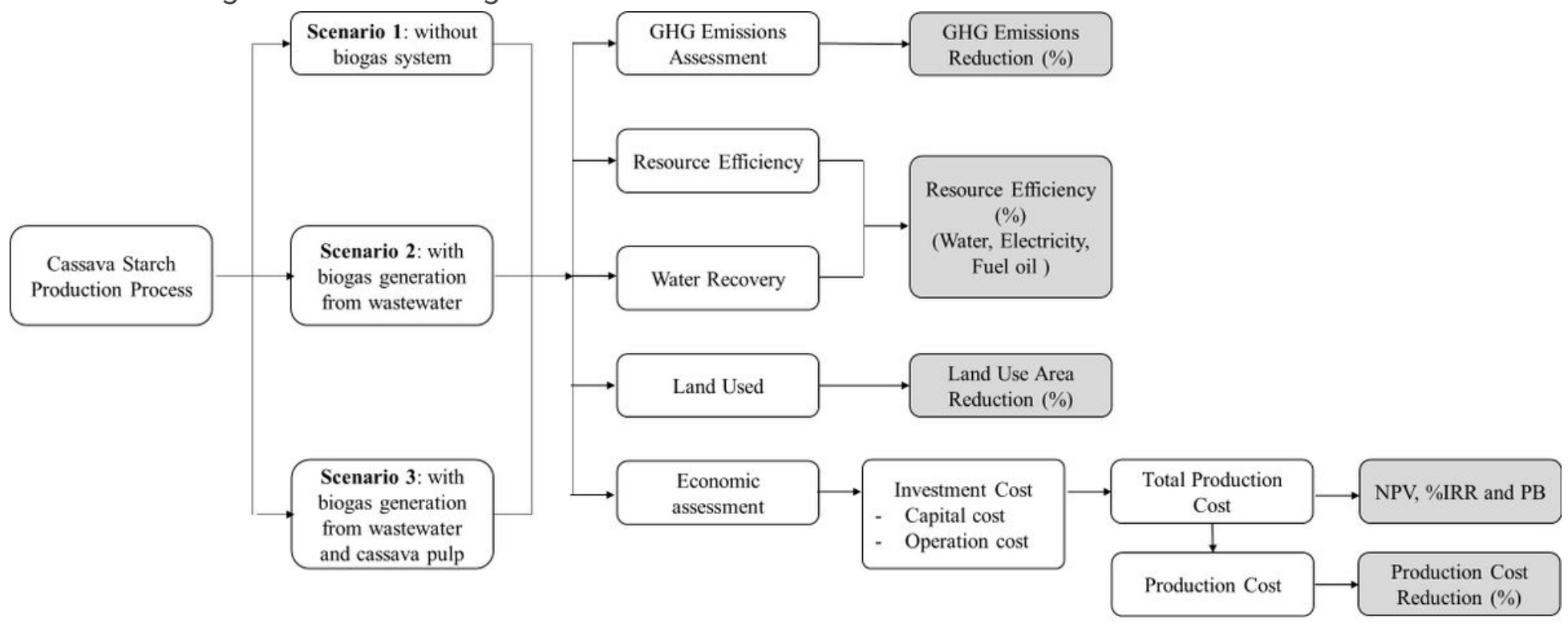

Figure 2

Research framework 


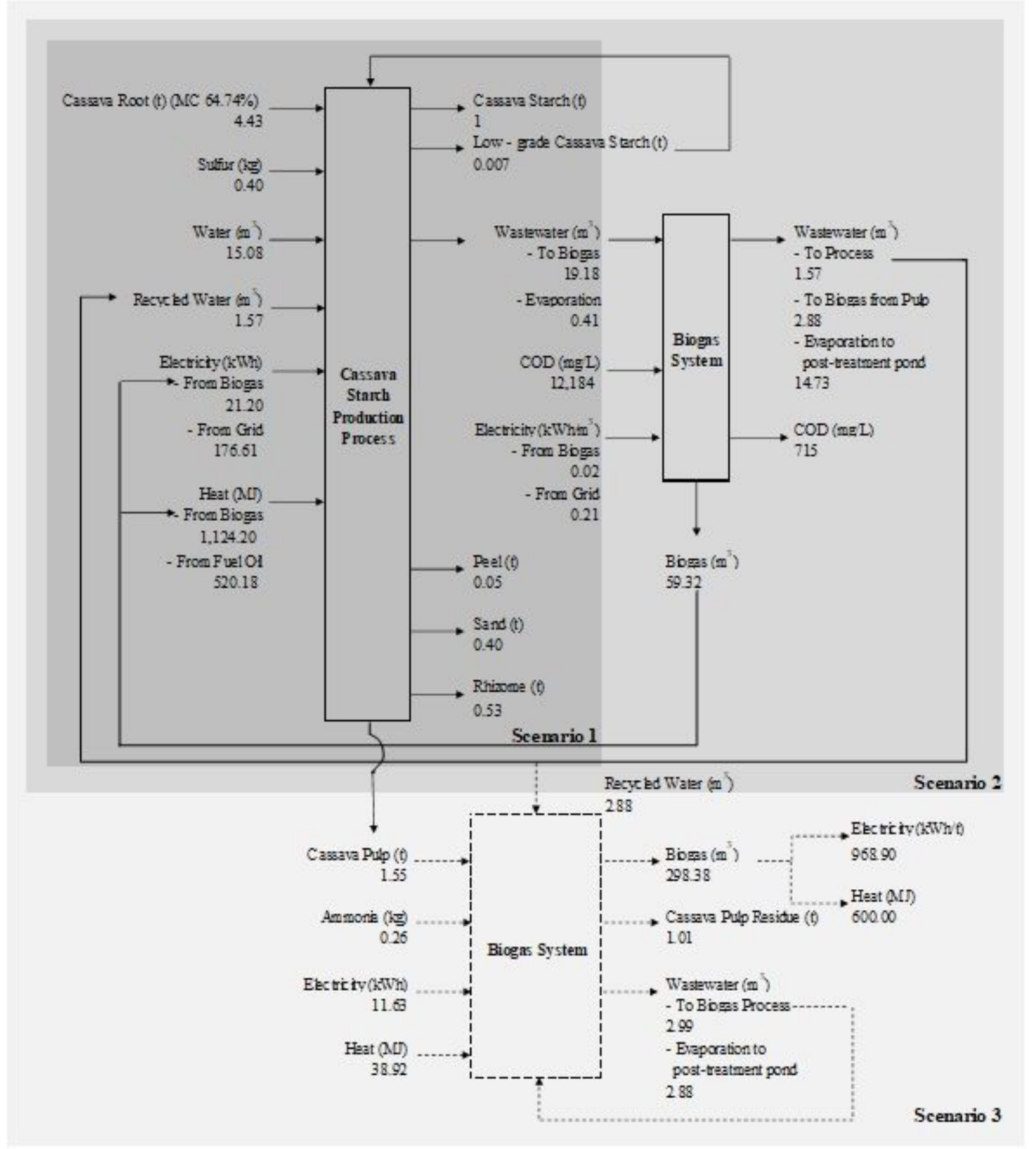

Figure 3

Resource consumption and waste generation (per one ton of cassava starch produced) from CSPP. Three scenarios of starch production consist of (1) scenario 1, without biogas system in factory, (2) scenario 2 , with biogas generation from wastewater, and (3) scenario 3, with biogas generation from wastewater and cassava pulp 


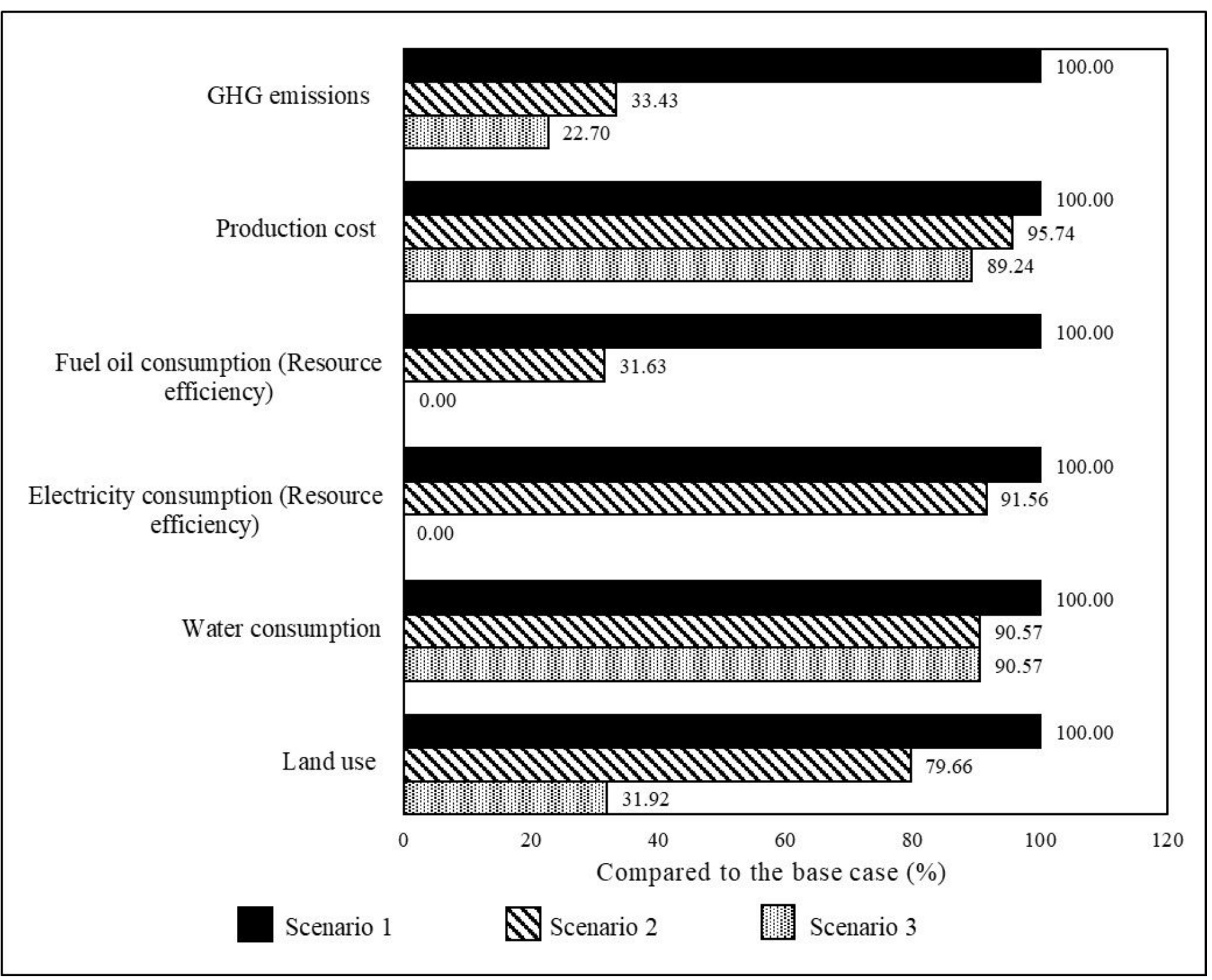

\section{Figure 4}

Overall reduction of GHG emission, production cost, resource use, and land use from the three scenarios of starch production. Scenario 1 is without a biogas system in factory, scenario 2 is with biogas generation from the wastewater, and scenario 3 is with biogas generation from both the wastewater and cassava pulp 